\title{
THE INFLUENCE OF TRUST ON COLLABORATIVE RELATIONSHIPS IN SUPPLY CHAINS
}

\author{
Sonja Mlaker Kac, Irena Gorenak, Vojko Potocan
}

\section{Introduction}

Collaborative business relationships have been considered as very important in business and academic world. Supply chains are defined as a set of three or more organizations directly involved in (the upstream and downstream) flows of products, services, finances and/or information from a source to a customer and where all companies strive to achieve the same goal (Mintzberg et al., 1996). So, collaborative behavior is very important for supply chain management.

We discuss and examine the influence of trust between partners in supply chain on collaborative behavior in supply chains. Our basis is KMV - key-mediating-variable model (Morgan \& Hunt, 1994), which places the role of trust as a central to successful partnerships with different stakeholders, including partners in supply chains.

The concept of an integrated logistical organization was introduced and generalized in early 1970's (Bowersox et al., 1989). Many firms have responded to dynamic business environment in last decades by building collaborative relationships in supply chains (Doney \& Cannon, 1997).

The researched topic involves several different point of views and impacts of marketing, organization, sociology and economics.

The aim of our article is to examine whether there is an influence of trust on collaborative behavior in supply chains and detect which are factors influencing trust and how strong are these influences. For partners in supply chain this can be an important issue when planning activities with partners in supply chains. We assume that trust is an important factor when companies want to achieve long-term successful relationships.

\section{Theoretical Background}

The main theories that we deal with in our research are social exchange theory and relationship commitment - trust theory, which point out the importance of trust in cooperative relationships. Relationship commitment trust theory also suggests that there are three crucial antecedents of trust: shared values, communication and opportunistic behavior (Morgan \& Hunt, 1994).

The relationship commitment trust theory points out the importance of marketing perspective in modern business world (Morgan \& Hunt, 1994; Deepen, 2007). Since it can be implemented to relationships with all partners of an organization: suppliers, buyers, lateral partners and internal partners. This theoretical background is very appropriate for our research.

Contemporary management theorists (Adobor, 2006) have continued to identify trust as one critical element for performance in strategic partnerships. One of forms of strategic partnerships is also supply chain (Adobor, 2006).

\subsection{Trust in Supply Chains}

Trust is a multidimensional concept (Svensson, 2005) and can be defined from several different perspectives: sociological, psychological, economical etc. point of view (Anderson \& Narus, 1984; Anderson \& Weitz, 1992; Morgan \& Hunt, 1994; Svensson, 2005; Young, 2006; Castaldo, 2007). And its definition differs from the context in which the concept has been researched (Nicholson et al., 2001).

Trust is from sociological point of view in general defined as "a willingness to rely on an exchange partner in whom one has confidence" (Bradach \& Eccles, 1989; Moorman et al., 1992). Trust exists when one party believes the other party has incentive to act in his or her 
interest or to take his or her interests to heart (Cook et al., 1995).

Trust can be also defined as a relationship (trust always results in a relationship as direct or indirect exchange and it points out the quality of a relationship), as personality trait (psychosocial perspective treats trust as a quality of a truster and not of the relationship between the truster and the trustee) and as a cultural rule (decisions to trust or distrust occur in the preexistent cultural context and normative rules push someone toward or away from trusting the other person or organization) (Sztompka, 1998). In sociological theory trust also means a reduction of social complexity (Luhmann, 1968; Castaldo, 2007).

Different authors (Morgan \& Hunt, 1994; Humphrey, 1998; Harland et al., 2004; Baron et al., 2010; Murphy \& Wood, 2011) argue that trust is very important factor influencing supply chain management relationships. It is recognized as an important element in successful, strategic relationships with suppliers (Harland et al., 2004; Castaldo, 2007).

Trust can influence the development of customer orientation, which means, the greater the level of trust, the more chance of a positive attitude being developed (Baron et al., 2010).

So, in business world trust is defined as the firm's belief that another company will perform actions that will result in positive outcomes for the firm as well as not take unexpected actions that result in negative outcomes (Anderson \& Narus, 1990).

Thus, there are many definitions of trust; we can group these definitions into two types of conceptualization. Trust can be defined as (1) a belief, sentiment or expectation about an exchange partner's trustworthiness. This results from expertise and reliability of partner in interaction. Trust can also mean (2) a behavior (or behavioral intention) that reflects a reliance on a partner and involves vulnerability and uncertainty on the part of the other party (in this case trustor) (Moorman et al., 1992).

Since we are researching inter-organizational relationships, it is important to discuss inter-organizational trust. Trust within interorganizational networks (such as supply chains are) support the formation of collective strategies, facilitate the coordination of economic activities, promote open exchange of information and open up opportunities for strategic action, enhance system stability and at the same time support organizational changes (Sydow, 1998). Since inter-organizational network is conceives of as a long term institutional arrangement among related organizations (Sydow, 1998) its definition of trust can be used as a basis for defining trust in supply chains.

Success of each company that cooperates with other companies depends on the actions taken by all other companies and enhances the uncertainty and risk. This means that trust is, on one hand, the precondition for collaboration and, on the other hand, also the product of successful collaboration (Sztompka, 1998).

The relations between trust and relationships, which also means relationship commitment, can be different. Trust was examined as a feature of relationship quality or as a determinant of relationship quality. In first case different authors view trust as a feature of relationships, in addition to power, communications and compatibility in addition to satisfaction. In second case trust determines relationship quality (Moorman et al., 1992).

Some authors (Morgan \& Hunt, 1994) claim that trust is required to produce collaboration in order to make societies function productively. Other authors (Cook et al., 1995) argue that trust works primarily at the interpersonal level. So, trust is no longer the central glue of social order (Cook et al., 1995).

In today's society every company cooperates with several different stakeholders: internal partners, supplier and buyer partners and also lateral partners (such as competitors and government) (Johanson \& Mattsson, 1987; Morgan \& Hunt, 1994; Chen \& Paulraj, 2004). Good and effective cooperation between organization and its stakeholders leads towards being better than other companies, so being better than organizations' competitors. At the end greater trust leads indirect and in many cases even directly to greater competitive advantage of an organization.

Trust can be seen as a key managerial concept and sometimes it is considered as $\mathrm{s}$ governance mechanism and other times as a mechanism to reduce opportunism in strategic networks (Kumar, 1996; Achrol, 1997). Trust reduces the uncertainty in a relationship (Skandrari et al., 2011). If one organization trusts another one, it will assign collaborative intentions to the trusted organization. Several studies have shown that inter-organizational trust leads toward a cooperative behavior 
between organizations (Jap \& Anderson, 2003; Payan \& Svensson, 2007).

Relationships characterized by trust are highly valued and parties will desire to commit themselves to such relationships (Morgan \& Hunt, 1994).

Next we will define three main antecedents of trust: shared values, communication and opportunistic behavior.

First, we have to consider shared meanings as an essential element for the constitution of social life (Humphrey, 1998). Shared values are included as important part in model of fundamental partnership variables (Dwyer et al., 1987; Morgan \& Hunt, 1994; Deepen, 2007) and in this context trust is produced among social actors when they hold shared beliefs and hence to build up mutual expectations (Humphrey, 1998).

Shared values are defined as the extent to which partners have beliefs in common about what behaviors, goals and policies are important or unimportant, appropriate or inappropriate, right or wrong (Morgan \& Hunt, 1994).

Furthermore, we will discuss communication. Communication is where an individual or a group of people establish a common and coordinated activity through the exchange information of concepts, suggestions and attitudes to obtain a specific goal (Wang, 2009). Relationship components are experienced through communication which is possible only if there is a two way flow of communication (Baron et al., 2010).

Improved (internal and external) communication enables the supply chain integration. It is difficult to find an area of logistics that is not affected by improved communication (Waters, 2007). Communication is essential in relationships as it implies dependence and commitment (Baron et al., 2010).

Effective and efficient communication with external markets is a fundamental marketing responsibility. Integrating outgoing marketing communication leads on long turn toward development of value exchanges with customers. One way messaging should be replaced by two way communication with several partners in supply chains (Christopher et al., 2009).

Effective inter-organizational communication can be characterized as frequent, genuine and involving personal contacts between buying and selling side (Brankenburg Holm et al., 1996).
Trust is often discussed in the context of opportunism (Humphrey, 1998). Therefore opportunism is often defined as an explanatory variable (Dwywer et al., 1987; Morgan \& Hunt, 1994; Knemeyer \& Murphy, 2004; Deepen, 2007). In business world opportunistic behavior is defined (Humphrey, 1998) as the organization intentionally transmitting incomplete or twisted information to others that would mislead, twist, hide or confuse others in interaction (Wang, 2009).

Opportunistic behavior could be active or passive, so it may occur when a party either engages in or refrains from particular actions (Heide \& John, 1992; Wathne \& Heide, 2000).

\subsection{Collaborative Behavior in Supply Chains}

Several authors (Moorman et al., 1992; Morgan \& Hunt, 1994; Humphrey, 1998; Denise, 1999; Harland et al., 2004; Knemeyer \& Murphy, 2004; Payan \& Svensson, 2007) pointed out the importance of working together in today's unstable economic and social environment. Basically, there are three different and frequently discussed and researched ways of working together: coordination, cooperation and collaboration (Denise, 1999; Pollard, 2005; Cao \& Zhang, 2013).

We will describe the collaboration as a form of modern relationship formation used in interorganizational alliances, and therefore in supply chains. Higher levels of integration allow a supply chain to work together (Waters, 2007).

Coordination (Pollard, 2005) is based on shared objectives and understanding of who needs to do what until when. It is problem resolution mechanism, where both sides in relationship want to efficiently receive results. Degree of interdependence is minimal. Coordination achieves efficiency of motion but tells us nothing about the consequence of motion (Denise, 1999).

Cooperation is defined as situations in which different partners work together so that they can achieve mutual goals (Anderson \& Narus, 1990; Cumming \& Bromiley, 1996). Cooperation means acting together, collectively. Both parties have the same common goal that cannot be achieved individually by each of them. This shows us that the success of each party depends on the actions taken by all others and enhances the uncertainty and risk (Sztompka, 1998). So, cooperation is based on 
shared objectives, mutual trust and respect and acknowledgment of mutual benefits of working together. The goal is that both sides efficiently receive results and at the same time save time and money. Degree of interdependence is considerable (Pollard, 2005).

Cooperation in business relationships means "working together to the same end" and can be regarded as understanding in coordinating exchange activities in the relationship (Brankenburg Holm et al., 1996).

Collaboration is based (Pollard, 2005) on shared objectives, sense of urgency, commitment and belonging, on open communication, mutual trust and respect, complementary skills and knowledge. The main goal is achieving innovative and extraordinary results efficiently. Degree of interdependence of partners in relational exchange is substantial. Collaboration (Denise, 1999) does not anchor in the process of relationship but in the pursuit of a specific result. Collaborations are established to solve problems, develop new understandings, design new products (Denise, 1999).

Supply chain collaboration is from all concepts the best concept to capture the joint relationship between autonomous supply chain partners. The collaboration means that the pie gets larger so that all partners can get a larger piece then they had before (Cao \& Zhang, 2013).

Based on social exchange theory, we can claim, that collaboration in inter-organizational relationships may be supported by trust (Dwyer et al., 1987).

\section{Research Model}

Having closely studied various scientific and professional literatures about relationship marketing and supply chain management we have determined that a combination of various theories could be included in our research model. We use key mediating variable model for the basis of our research and so we set a trust as a main variable that influence collaborative relationships in supply chains. According to the theory three main antecedents of trust are shared values, communication and opportunistic behavior. We adapted those factors to our model, shown in Fig. 1.

Trust can be seen as a determination of the amount of cooperation between parties (Anderson \& Narus, 1990; Morgan \& Hunt, 1994). Mutual trust can be seen as an antecedent of cooperative behaviors (Castaldo, 2007). Shared values, communication and opportunistic behavior are seen as key factors influencing trust (Morgan \& Hunt, 1994). We predict that shared values and communication influence trust positive and opportunistic behavior negative.

The aim of the research was to test the validity of the model shown in Fig. 1 . To this

\section{Fig. 1: Research model}

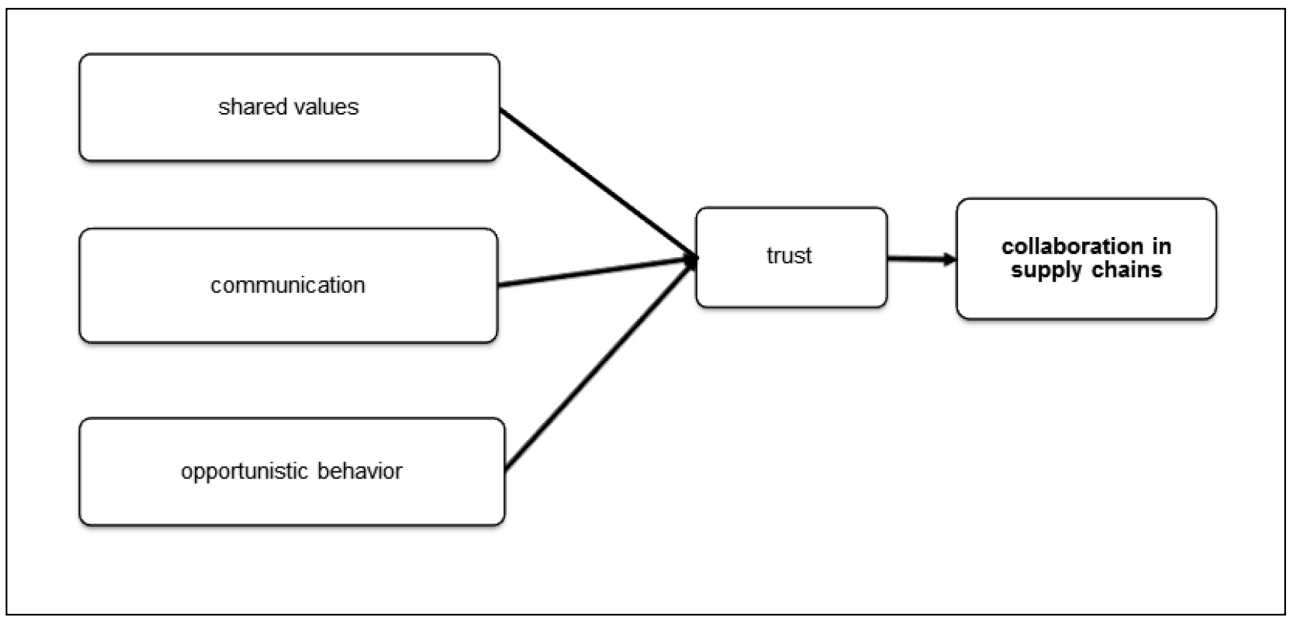


end, our main research question was: Is there a statistically significant influence of trust on collaboration in supply chains?

In order to answer this research question the following research hypothesis was set up:

H1: Trust has a statistically significantly positive influence on collaboration in supply chains.

Through trust better understanding of strategic and managerial collaboration and long term orientation can be achieved (Skandrari et al., 2011).

As it is seen from research model, we also research antecedents of trust. So we also discuss following hypothesis:

H2: Shared values have a statistically significantly positive influence on trust in supply chains.

Several authors (Anderson \& Narus, 1990; Morgan \& Hunt, 1994; Zineldin \& Jonsson, 2000; Wang, 2009) have pointed out the important issue of shared values between organizations influencing business to business relationships. Shared values as the foundation of trust signify that both parties have similar symbolic system and explanatory logic which means that the goal and benefits of both parties can be compatible (Wang, 2009).

H3: Communication has a statistically significantly positive influence on trust in supply chains.

Different studies (Anderson \& Narus, 1990; Denise, 1999; Zineldin \& Jonsson, 2000; Wang, 2009) have shown that communication is one of the main antecedents of trust. According to these researches (Anderson \& Narus, 1990; Zineldin \& Jonsson, 2000; Wang, 2009) made on different inter-organizational relationships communication and trust have positive relationship.
H4: Opportunistic behavior has a statistically significantly negative influence on trust in supply chains.

Opportunistic behavior can hurt trusting relationship of two parties involved in a relationship (Wang, 2009) and different studies (Deepen, 2007; Morgan \& Hunt, 1994; Zineldin \& Jonsson, 2000; Wang, 2009) have shown that opportunistic behavior has a negative influence on trust in inter-organizational relationships and would reduce trust between organizations. According to research made on topic buyer's risk of third party opportunism opportunistic behavior has a negative influence on trusting relationships between partners (Moore, 1998).

\section{Methodological Framework}

The correlations were tested using an online questionnaire survey. Logistics managers, chief buyers, sales managers, project managers and employees in logistics departments were included in our online survey (see Tab. 1). The survey was made in the primary, secondary and tertiary sector of Slovene economy (see Tab. 2). We included companies of all sizes (see Tab. 3 ), both local and foreign ones with a presence in Slovenia (see Tab. 4). Our research was made in November and December 2013. There were 118 questionnaires completed and used in the research.

According to the demographic data, our sample reflects the population in terms of economy branch and size of companies. Based on the findings we can conclude that the research sample could be generalized to the whole population.

The questionnaire comprised 38 statements related to (1) collaboration in supply chains, (2)

Tab. 1: Employees included in the survey

\begin{tabular}{l|c|c}
\multicolumn{1}{c|}{ Position of employees } & Responses & \% \\
\hline Logistics managers & 26 & 22.2 \\
\hline Project managers (with logistics tasks) & 25 & 21.4 \\
\hline Chief buyers & 24 & 20.5 \\
\hline Sales managers & 17 & 14.5 \\
\hline Employees in logistics departments & 20 & 17.1 \\
\hline Total & $112^{*}$ & 100.0 \\
\hline
\end{tabular}

*Only 112 out of 118 respondents that finished our survey answered to this question. 


\section{Tab. 2: Sectors included in the survey}

\begin{tabular}{l|c|c}
\multicolumn{1}{c|}{ Sector } & Responses & $\%$ \\
\hline Primary & 3 & 2.6 \\
\hline Secondary & 45 & 38.5 \\
\hline Tertiary & 69 & 58.9 \\
\hline Total & 118 & 100.0 \\
\hline
\end{tabular}

Source: own

\section{Tab. 3: Size of organizations included in the survey}

\begin{tabular}{l|c|c}
\multicolumn{1}{c|}{ Size } & Responses & $\%$ \\
\hline Micro & 50 & 42.7 \\
\hline Small & 32 & 27.3 \\
\hline Medium & 17 & 14.5 \\
\hline Large & 18 & 15.4 \\
\hline Total & $117^{* *}$ & 100.0 \\
\hline
\end{tabular}

${ }^{* *}$ Only 117 out of 118 respondents that finished our survey answered to this question.

\section{Tab. 4: Local/foreign organizations included in the survey}

\begin{tabular}{l|c|c}
\multicolumn{1}{c|}{ Type } & Responses & $\%$ \\
\hline Local & 57 & 49.6 \\
\hline Foreign & 58 & 50.4 \\
\hline Total & $115^{\text {** }}$ & 100.0 \\
\hline
\end{tabular}

***Only 115 out of 118 respondents that finished our survey answered to this question.

trust, (3) shared values, (4) communication, (5) opportunistic behavior and (6) respondents' details (age, gender, number of working years, level of education etc.).

\section{Research Results}

Factor analysis produced a combination of five factors ((1) collaboration in supply chains, (2) trust, (3) shared values, (4) communication, (5) opportunistic behavior) and we examined the relationships and influences among them. We tested the validity of the questionnaire using the Cronbach's alpha test, calculating the coefficient for each set of variables, which were merged in factors. We have performed this test on variables that measured collaboration first; the value was 0.864 , which indicate great reliability of measurement. The value of Cronbach's alpha test for variables that measured trust was 0.877 , for variables measuring communication 0.779 , for variables measuring shared values the value was 0.832 and for variables measuring opportunism the value was 0.832 . These values indicate great reliability of measurement.

After forming new merged variables (factors) we have measure mean values and standard deviations in these newly formed factors. Results are shown in Tab. 5. 


\section{Tab. 5: Mean values and standard deviations of measured factors}

\begin{tabular}{l|c|c} 
& Mean value & Standard deviation \\
\hline Collaboration & 3.70 & 0.59 \\
\hline Trust & 3.48 & 0.68 \\
\hline Communication & 3.67 & 0.68 \\
\hline Shared Values & 3.63 & 0.69 \\
\hline Opportunism & 3.52 & 0.68 \\
\hline
\end{tabular}

Source: own

Tab. 6: Correlations between measured factors

\begin{tabular}{|c|c|c|c|c|c|}
\hline & $\begin{array}{c}\text { Collabora- } \\
\text { tion }\end{array}$ & Trust & $\begin{array}{l}\text { Communi- } \\
\text { cation }\end{array}$ & $\begin{array}{l}\text { Shared } \\
\text { Values }\end{array}$ & Opportunism \\
\hline Collaboration & 1 & & & & \\
\hline Trust & $0.732^{* *}$ & 1 & & & \\
\hline Communication & & $0.604^{* *}$ & 1 & & \\
\hline Shared Values & & $0.603^{\star *}$ & & 1 & \\
\hline Opportunism & & $-0.594^{\star *}$ & & & 1 \\
\hline
\end{tabular}

** $p \leq 0.01$

Source: own

Further interest was related to the measurement of correlations between factors collaboration, trust, communication, shared values and opportunism. Therefore the Pearson's correlation coefficient test was examined and results are shown in Tab. 6.

Among the data shown in Tab. 6 we have highlighted the correlations that we are according to the model interested in. All the highlighted correlations are important for the research model.

Closer look to the results shows the strongest correlations among research models is correlation between trust and collaborative behavior $\left(0.732^{* *}\right)$. The correlations between trust on one hand and communication and shared values on the other hand are quite similar $\left(0.603^{* *}\right.$ - correlation shared values - trust; $0.604^{* *}$ - correlation communication - trust). The correlation between trust and opportunism $\left(-0.594^{* *}\right)$ is negative and semi strong.

We have also conducted a linear regression analysis, where the influence of independent variables towards dependent variables has been analyzed. The influence of each of the independent variables was evaluated separately, so that it does not depend on influences between various independent variables. Tab. 7 demonstrates the values of regression among pairs of variables, as proposed in our research model:

- trust (as independent factor) - collaboration (as dependent factor),

- shared values (as independent factor) trust (as dependent factor),

- communication (as independent factor) trust (as dependent factor),

- opportunism (as independent factor) - trust (as dependent factor).

Tab. 7 shows the results of linear regression analysis. The first pair includes the independent variable trust and the dependent variable collaboration. Results $\left(\Delta \mathrm{R}^{2}=0.532 ; \mathrm{F}=\right.$ 133.973; $p=0.000$ ) show that the influence of trust can explain $53.2 \%$ of variability of value collaboration. The regression analysis for the second pair (independent variable shared values and dependent variable trust) shows $\left(\Delta R^{2}=0.358 ; F=65.555 ; p=0.000\right)$ that the 
Tab. 7: Regression analysis between measured factors

\begin{tabular}{l|c|c|c}
\multicolumn{1}{c|}{ Regression } & $\boldsymbol{\Delta R}^{2}$ & $\mathbf{F}$ & $\mathbf{P}$ \\
\hline Trust - collaboration & 0.532 & 133.973 & 0.000 \\
\hline Shared values - trust & 0.358 & 65.555 & 0.000 \\
\hline Communication - trust & 0.359 & 65.904 & 0.000 \\
\hline Opportunism - trust & 0.347 & 62.566 & 0.000 \\
\hline
\end{tabular}

Source: own

influence of shared values explain $35.8 \%$ of variability of value trust. In the third pair we mark the independent variable communication and the dependent variable trust. The findings show $\left(\Delta R^{2}=0.359 ; F=65.904 ; p=0.000\right)$ that the influence of communication can explain $35.9 \%$ of variability of value trust. The fourth pair was opportunism (as independent variable) and trust (as dependent variable). Results $\left(\Delta R^{2}\right.$ $=0.347 ; F=62.566 ; p=0.000$ ) show that the influence of opportunism explain $34.7 \%$ of variability of value trust.

The results of our research are the best shown in Fig. 2.

\section{Fig. 2: Research model with results}

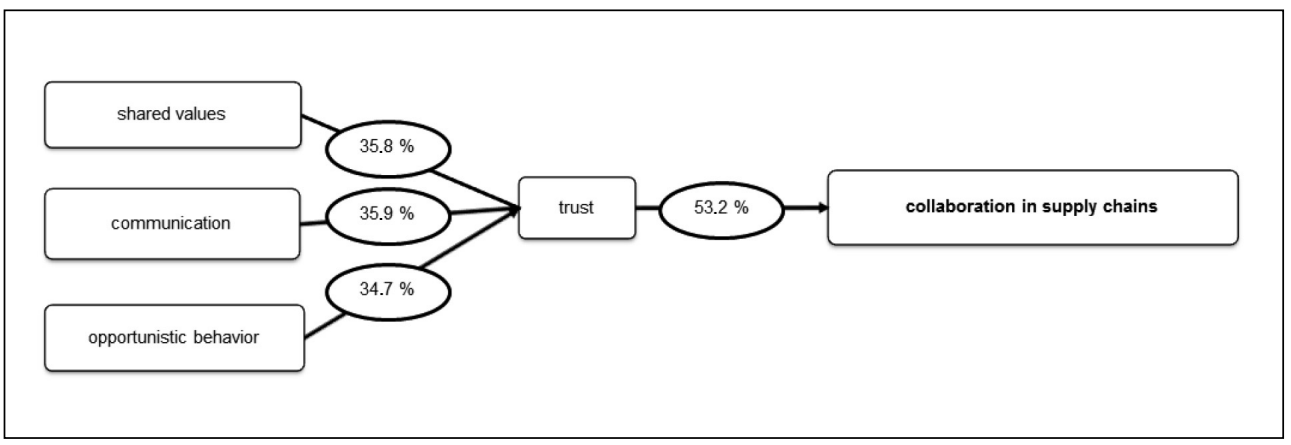

Source: own

Based on the results presented above (the Pearson's correlation coefficient and the linear regression analysis), we can confirm our main hypothesis $\mathrm{H} 1$ : "Trust has a statistically significantly positive influence on collaboration in supply chains."

Results also show that we can confirm hypothesis H2: "Shared values have a statistically significantly positive influence on trust in supply chains."

Furthermore, we can confirm hypothesis H3: "Communication has a statistically significantly positive influence on trust in supply chains."

At the end, also hypothesis $\mathrm{H} 4$ : "Opportunistic behavior has a statistically significantly negative influence on trust in supply chains." can be confirmed.

\section{Conclusions}

We can say for sure that every organization needs to build good, long term partnerships with all stakeholders, which means in our study with all partners in supply chains. Only such organization can see the possible threats and recognize them in time and prepare solutions. If all partners work together for their own good (suppliers', buyers', lateral partners' and internal partners' good) and have the same goal, that they want to achieve, the success cannot fall behind. 
As seen from the results of our research, trust is very important in achieving supply chain collaboration, which means that managers have to be aware of this and try to build trust in their business activities with partners in supply chains. Our research also shows that shared values, communication and opportunistic behavior influences trust in a great way. Shared values and communication between partners in supply chains have positive and opportunistic behavior has negative influence on trust. These are also concepts that have to be taken in consideration, when planning long term interorganizational relationships with partners in supply chains.

Good relationships in supply chains can be achieved only in good collaboration. To sum up, we can confirm that there is a statistically significant influence of trust on collaborative behavior in supply chains. The results clearly indicate that all factors included in research (trust, shared values, communication, opportunistic behavior) are very important for today's supply chain management. Managers should take these finding into consideration when they manage supply chains.

\section{References}

Achrol, R.S. (1997). Changes in the theory of interorganizational relations in marketing: toward network paradigm. Journal of the Academy of Marketing Science, 25(1), 56-171. doi:10.1007/BF02894509.

Adobor, H. (2006). Optimal trust? Uncertainty as determinant and limit to trust in inter-firm alliances. Leadership \& Organization Development Journal, 27(7), 537-553. doi:10.1108/01437730610692407.

Anderson, E., \& Weitz, B. (1992). The Use of Pledges to Build and Sustain Commitment in Distribution Channels. Journal of Marketing Research, 29(1), 18-34. doi:10.2307/3172490.

Anderson, J.C., \& Narus, J.A. (1984). A model of the distributor's perspective of distributor- manufacturer working relationship. Journal of Marketing, 48(4), 62-74. doi:10.2307/1251511.

Anderson, J.C., \& Narus, J.A. (1990). A Model of Distributor Firm and Manufacturer Firm Working Partnership. Journal of Marketing, 54(1), 42-58. doi:10.2307/1252172.

Baron, S., Conway, T., \& Warnaby, G. (2010). Relationship Marketing: A Consumer Experience Approach. London: Sage
Publications. doi:10.4135/9781446251096.

Bowersox, D.J., Daugherty, P.J., Droge, C.R., Rogers, D.S., \& Wardlow, D.L. (1989). Leading Edge Logistics: Competitive Logistics for the 1990's. Oak Brook (IL): Council of Logistics Management.

Bradach, J., \& Eccles, R.G. (1989). Price, Authority and Trust: From Ideal Types to Plural Forms. Annual Review of Sociology, 15(August), 97-118. doi:10.1146/annurev. so.15.080189.000525.

Brankenburg Holm, D., Eriksson, K., \& Johanson, J. (1996). Business Networks and Cooperation in International Relationships. Journal of International Business Studies, 27(5), 1033-1053. doi:10.1057/palgrave. jibs.8490162.

Cao, M., \& Zhang, Q. (2013). Supply Chain Collaboration. London: Springer Verlag. doi:10.1007/978-1-4471-4591-2.

Chen, I.J., \& Paulraj, A. (2004). Towards a theory of supply chain management: the constructs and measurements. Journal of Operations Management, 22(2), 119-150. doi:10.1016/j.jom.2003.12.007.

Cook, K.S., Hardin, R., \& Levi, M. (1995). Cooperation without Trust? New York: The Russell Sage Foundation.

Castaldo, S. (2007). Trust in market relationships. Cheltenham: Edward Elgar.

Christopher, M., Payne, A., \& Ballantyne, D. (2009). Relationship Marketing: Creating Stakeholder Value. Oxford: ButterworthHeinemann.

Cumming, L.L., \& Bromiley, P. (1996). The organizational trust inventory (OTI): development and validation. In R.M. Kramer, \& T.R. Tayler (Eds.), Trust in Organizations: Frontiers of Theory and Research (pp. 302330). Thousand Oaks: Sage.

Deepen, J.M. (2007). Logistics Outsourcing Relationships: Measurement, Antecedents and Effects of Logistics Outsourcing Performance. Heidelberg: Physica Verlag.

Denise, L. (1999). Collaboration vs. C-Three (Cooperation, Coordination and Communication). Innovating, 7(3), 1-6.

Doney, P., \& Cannon, J. (1997). An examination of the nature of trust in buyer seller relationships. Journal of Marketing, 61(2), 3551. doi:10.2307/1251829.

Dwyer, F.R., Schurr, P.H., \& Oh, S. (1987). Developing Buyer-Seller Relationships. Journal of Marketing, 51(2), 11-27. doi:10.2307/1251126. 
Harland, C., Knight, L., \& Cousins, P. (2004). Supply Chain Relationships. In S. New, \& R. Westbrook (Eds.), Understanding Supply Chains (pp. 209-228). Oxford: University Press.

Heide, J.B., \& John, G. (1992). Do norms matter in marketing relationships? Journal of Marketing, 56(2), 32-44. doi:10.2307/1252040.

Humphrey, J. (1998). Trust and the Transformation of Supplier Relations in Indian Industry. In C. Lane, \& R. Bachmann (Eds.), Trust Within and Between Organizations: Conceptual Issues and Empirical Applications (pp. 214-240). Oxford: Oxford University Press.

Jap, S.D., \& Anderson, E. (2003). Safeguarding interorganiozational perfomance and continuity under ex post opportunism. Management Science, 49(12), 1684-1701. doi:10.1287/mnsc.49.12.1684.25112.

Johanson, J., \& Mattsson, L.G. (1987). Interorganizational relations in industrial systems: a network approach compared with the transaction cost approach. International Studies of Management and Organization, 17(1), 34-48. doi:10.1080/00208825.1987.11656444.

Knemeyer, A.M., \& Murphy, P.R. (2004). Evaluating the Performance of Third-Party Logistics Arrangements: A Relationship Marketing Perspective. The Journal of Supply Chain Management, 40(4), 35-51. doi:10.1111/ j.1745-493X.2004.tb00254.x.

Kumar, N. (1996). The Power of Trust in Manufacturer-Retailer Relationships. Harvard Business Review, 74(6), 92-106. doi:10.1225/96606.

Luhmann, N. (1968). Vertrauen: ein Mechanismus der Reduktion Sozialer Komplexitaet. Stuttgart: Ferdinand Enke Verlag.

Mintzberg, H., Jorgensen, J., Dougherty, D., \& Westley, F. (1996). Some Surprising Things About Collaboration. Knowing How People Connect Makes It Work Better. Organizational Dynamics, 25(1), 60-71. doi:10.1016/S00902616(96)90041-8.

Moore, K.R. (1998). Trust and Relationship Commitment in Logistics Alliances: A Buyer Perspective. International Journal of Purchasing and Materials Management, 34(1), 24-37.

Moorman, C., Zaltman G., \& Deshpande, R. (1992). Relationship between Providers and Users of Marketing Research: The Dynamics of Trust Within and Between Organizations. Journal of Marketing Research, 29(3), 314-328. doi:10.2307/3172742.

Morgan, R.M., \& Hunt, S.D. (1994). The Relationship Commitment-Trust
Theory. Journal of Marketing, 58(3), 20-38. doi: $10.2307 / 1252308$.

Murphy, P.R., \& Wood, D.F. (2011). Contemporary Logistics. Boston: Prentice Hall.

Nicholson, C.Y., Compeau, L.D., \& Sethi, R. (2001). The role of interpersonal liking in building trust in long-term channel relationships. Journal of the Academy of Marketing Science, 28(1), 3-15. doi:10.1177/0092070301291001.

Payan, J.M., \& Svensson, G. (2007). Cooperation, coordination and specific assets in inter-organisational relationships. Journal of Marketing Management, 23(7-8), 797-814. doi:10.1362/026725707X230045.

Pollard, D. (2005). Business Innovation. Retrieved April 9, 2015, from http://howtosavetheworld.ca/2005/03/25/will-that-becoordination-cooperation-or-collaboration/.

Skandrari, H., Triki, A., \& Baratli, B. (2011). Trust In Supply Chains, Meanings. Determinants and Demonstrations: A qualitative study in an emerging market context. Qualitative Market Research: An International Journal, 14(4), 391409. doi:10.1108/13522751111163227.

Svensson, G. (2005). Mutual and interactive trust in business dyad: Condition and process. European Business Review, 17(5), 411-427. doi:10.1108/09555340510620320.

Sydow, J. (1998). Understanding the Constitution of Interorganizational Trust. In C. Lane, \& R. Bachmann (Eds.), Trust Within and Between Organizations: Conceptual Issues and Empirical Applications (pp. 31-63). Oxford: Oxford University Press.

Sztompka, P. (1998). Trust. A Sociological Theory. Cambridge: Cambridge University Press.

Young, L. (2006). Trust: looking forward and back. Journal of Business and Industrial Marketing, 21(7), 439-444. doi:10.1108/08858620610708920.

Wang, J.S. (2009). Trust and relationship commitment between direct selling distributors and customers. African Journal of Business Management, 3(12), 862-870. doi:10.5897/ AJBM09.318.

Waters, D. (2007). Trends in the supply chain. In D. Waters (Ed.), Global Logistics: New Directions in Supply Chain Management (pp. 1-20). London, Philadelphia: Kogan Page.

Wathne, K.H., \& Heide, J.B. (2000). Opportunism in interfirm relationships: forms, outcomes and solutions. Journal of Marketing, 64(4), 36-51. doi:10.1509/ jmkg.64.4.36.18070. 


\section{Ekonomika a management}

Zineldin, M., \& Jonsson, P. (2000). An examination of the main factors affecting trust/ commitment in supplier-dealer relationships: An empirical study of the Swedish wood industry. TQM Magazine, 12(4), 245-283. doi:10.1108/09544780010325831.
Sonja Mlaker Kac, PhD University of Maribor Faculty of Logistics sonja.mlaker-kac@um.si

Assoc. Prof. Irena Gorenak, PhD University of Maribor Faculty of Logistics irena.gorenak@um.si

Prof. Vojko Potocan, PhD University of Maribor Faculty of Economics and Business vojko.potocan@um.si 


\section{Abstract}

\section{THE INFLUENCE OF TRUST ON COLLABORATIVE RELATIONSHIPS IN SUPPLY CHAINS}

\section{Sonja Mlaker Kac, Irena Gorenak, Vojko Potocan}

In this paper we theoretically discuss and empirically examine the influence of trust on collaborative behavior in supply chain relationships. These concepts are very important in today's interorganizational business world, and therefore in supply chains.

In theoretical part of this article we presume that establishment and development of relationships in supply chain depends on development of trust. Trust is defined as a willingness to rely on a partner in a supply chain in whom one has confidence. The stress is on expectation that another partner can be relied on to fulfill obligations and at the same time previous experience with partners in exchange relationships are taken in the consideration. Collaborative behavior is defined as a concept where two or more organizations, which work together in a supply chains, can through complementary characteristics gain shared means and goals that could not be achieved individually.

Logistics managers, purchase and sales managers, project managers and employees in logistics department were included in our survey made on primary, secondary and tertiary sector of Slovene economy. We included companies of all sizes, both local and foreign companies present in Slovenia. 118 questionnaires were completed and involved in our research. According to the demographic data, our sample is comparable to population in terms of economy branch and size of companies.

The Pearson correlation coefficient and linear regression analysis demonstrate statistically significant strong correlation between trust, shared values and communication and strong negative correlation between trust and opportunistic behavior. At the end we can confirm that there is a statistically significant influence of trust on collaborative behavior in supply chains. The results clearly indicate that all factors included in research are very important for today's supply chain management.

Key Words: Trust, collaborative behavior, shared values, communication, opportunism, supply chain.

JEL Classification: M11.

DOI: 10.15240/tul/001/2016-2-008 